\title{
THE ORGANIZATIONAL LEGITIMACY OF RUSSIAN FIRMS: CONTEXTUAL SPECIFICITY AND LEGITIMIZATION STRATEGIES
}

\author{
A. YU. PANIBRATOV, L. E. RYSAKOVA \\ Graduate School of Management, St. Petersburg State University, Russia
}

\begin{abstract}
Russian firms suffer from the negative country of origin effect and legitimacy shortage. This paper has the aim to reveal factors for Russian firms to focus on while build legitimacy both at home and abroad. To identify the existing research directions, the 48 articles applying legitimacy and Russian focus from journals in management and business for all years were analyzed, using both the bibliometric analysis and manual in-depth study of papers. Based on the specificity of the Russian context and literature analysis about the factors of the legitimacy concept, we develop a theoretical framework that is supported by a set of propositions about possible legitimization strategies of Russian firms. Three main pillars of the organizational legitimacy construct such as moral, pragmatic and cognitive, which are accepted as the most influential ones, were introduced and proposed for Russian firms how to gain them at home and abroad. This paper has the value for both theory and practice. It contributes to the legitimacy literature, responding to many calls to study the microfoundations of the organizational legitimacy and developing the holistic theoretical framework within the Russian context. The findings also are of practical importance for managers and entrepreneurs whose attention is paid to the effective strategic management and legitimacy building both at home and abroad.

Keywords: liability of foreignness, liability of outsidership, organizational legitimacy, moral legitimacy, pragmatic legitimacy, cognitive legitimacy, Russia.
\end{abstract}

JEL: L20.

\section{INTRODUCTION}

Organizational legitimacy is a key concept of the institutional theory, which introduces specific strategies helping to reduce the neg- ative impact of firms' liability of foreignness and outsidership [Johanson, Vahlne, 2009; Kostova, Zaheer, 1999]. These strategies contribute for gaining and managing legitimacy in new institutional contexts [Caussat,

Postal Address: 3, Volkhovskiy per., Graduate School of Management, St. Petersburg State University, St. Petersburg, 199004, Russia.

(C) A. Yu. Panibratov, L. E. Rysakova, 2020

https://doi.org/10.21638/spbu18.2020.301 
Prime, Wilken, 2019; Kostova, Zaheer, 1999]. Organizational legitimacy is applied as "a generalized perception or assumption that the actions of an entity are desirable, proper, or appropriate within some socially constructed system of norms, values, beliefs, and definitions" [Suchman, 1995, p. 574]. Although there are many pillars of the organizational legitimacy construct, the most influential ones are moral, cognitive and pragmatic [Suddaby, Bitektine, Haack, 2017], which are proposed by [Suchman, 1995].

Legitimacy gaining is important for both domestic home and foreign markets during and after internationalization [Kostova, Zaheer, 1999]. Acquiring the legitimacy in the home market is a necessary step that also facilitates access to foreign ones [Prashantham, Kumar, Bhattacharyya, 2019], in which the organizational legitimacy is the driving force for firms' success [Kostova, Zaheer, 1999]. Thus, the organizational legitimacy has the impact on companies' performance in new markets via increased profitability and approval by the civil society and prospective partners [Zimmerman, Zeitz, 2002; Caussat, Prime, Wilken, 2019]. Most papers have introduced sociopolitical activism, transference and isomorphism, which follow from the institutional theory, as three main strategies that help to acquire the organizational legitimacy in a new market [Deephouse, 1996; Caussat, Prime, Wilken, 2019]. They relate to the macrolevel of firms and their institutional environment and ignore the specific practices that companies really use for realization of these strategies [Kostova, Roth, Dacin, 2008; Caussat, Prime, Wilken, 2019]. Thus, this view lacks "the microlevel of the firms' strategies" that organizations can apply to gain or maintain their legitimacy [Caussat, Prime, Wilken, 2019 , p. 562]. Because very little is known about the possible sources and practices that are engaged by companies to gain and manage their legitimacy, there is a call for more studies in order to analyze the specific micro-level of the formation of firms' legitimacy [Caussat, Prime, Wilken, 2019;
Kostova, Roth, Dacin, 2008]. This is important for providing specific determinants of what companies can really do to gain and manage their organizational legitimacy. Moreover, this can be applied to many contexts and differ among them [Kostova, Roth, Dacin, 2008].

Nowadays countries with emerging economies are considered as the main economic growth engine in the world via their contribution to investment activities in other countries and, generally, world's GDP [Puffer et al., 2013; UNCTAD, 2019]. Russia has become one of the biggest investors among the group of countries with transition economies. Thus, Russia is a provider of foreign direct investments (outflow FDI) globally accounting for $\$ 34$ bln in 2017 year, $\$ 36$ and $\$ 23$ bln in 2018 and 2019 years respectively [UNCTAD, 2019; 2020]. There also is the increased number of Russian firms that operate abroad or have the great incentives to do so [Panibratov, 2015; Panibratov et al., 2018].

The organizational legitimacy concept has received the significant consideration in a literature over the past decades [Suchman, 1995; Caussat, Prime, Wilken, 2019]. Studies from the developed markets pay much attention to the organizational legitimacy of firms, but studies in the rest of the world, especially in the emerging market context, are quite scarce, which is strange, given the increasing expansion of such companies into international markets over the past two decades and, generally, their strong incentives to operate abroad [Panibratov, Ermolaeva, Abramkov, 2015; Ai, Tan, 2020]. However, Russian firms suffer from the negative country of origin (COO) effect and legitimacy shortage both at home and abroad that complicate their internationalization [Ermolaeva et al., 2019; Panibratov et al., 2018; Petrovskaya, Zaverskiy, Kiseleva, 2017].

The study is a two-step research that applies such methods as the bibliometric analysis and manual in-depth articles' search. First, we identify main research directions of existing studies with Russian and legitimacy focus. Second, on the basis of speci-

PЖM 18 (3): 289-312 (2020) 
ficity of the Russian context and literature analysis about the factors of legitimacy, we develop a theoretical framework that is supported by a set of propositions. Based on the literature review, we identify that for Russian firms legitimacy building abroad most studies have emphasized the organizational isomorphism and just some research introduced specific practices that can mitigate the liability of foreignness [Panibratov, 2015; Panibratov et al., 2018]. As for the internal Russian market: although some of the Russian context' challenges are identified, there are not any specific strategies introduced how to overcome them by firms. We expect to elaborate and fill these gaps revealing essential factors for Russian firms to focus on while build legitimacy simultaneously on both directions in Russia and abroad. Moreover, this paper even deep the analysis by dividing the legitimacy construct into three pillars such as moral, pragmatic and cognitive and introducing the concept of liability of outsidership [Johanson, Vahlne, 2009; Suchman, 1995].

The paper is organized as follows. We begin with the theoretical scope of the organizational legitimacy concept. Then, based on the literature analysis and features of the Russian context, we develop a theoretical framework that is supported by a set of propositions. We provide the literature analysis in order to systematize the existing papers with the Russian market as a context for legitimacy research and identify factors that influence various pillars of legitimacy. Then, we discuss how Russian firms can gain legitimacy both at home and abroad. Finally, we conclude and discuss our results.

\section{THEORETICAL BACKGROUND}

\subsection{The organizational legitimacy concept}

Legitimacy is a fundamental concept of the institutional theory that emphasized strat- egies to reduce the negative impact of liability of foreignness and outsidership by acquiring and proceeding legitimacy [Caussat, Prime, Wilken, 2019; Kostova, Zaheer, 1999]. Firms are legitimate, when they are seen as appropriate for a specific social context in new business and institutional environments [Tost, 2011]. Most researchers have applied the institutional theory and assumed it from a neoinstitutional perspective in which legitimacy acquisition and maintaining are vital processes for firms' survival [Caussat, Prime, Wilken, 2019; Kostova, Roth, Dacin, 2008]. For successful performance, the legitimacy of firms must be established first in the domestic market and then be based abroad [Prashantham, Kumar, Bhattacharyya, 2019].

Due to limited knowledge about the new foreign market institutional and business environments, companies' internationalization process can carry high uncertainty and costs [Zaheer, 1995]. It can lead to firms' liability of foreignness and outsidership [Johanson, Vahlne, 2009; Kostova, Zaheer, 1999; Zaheer, 1995]. Liability outsidership means the firms' position outside the relevant business network in a particular market [Johanson, Vahlne, 2009]. Gaining legitimacy in the home market is a necessary step to overcome liability of outsidership but establishing legitimacy abroad is a different process that demand some special firms' abilities to cover both liability of foreignness and outsidership [Li, Fleury, 2020; Prashantham, Kumar, Bhattacharyya, 2019]. The liability of foreignness of companies occurs due to a lack of local tacit knowledge about a new foreign institutional environment such as language, laws and rules, culture so on [Johanson, Vahlne, 2009; Zaheer, Lamin, Subramani, 2009]. Whereas, the liability of outsidership of firms emerges due to a lack of specific business environment knowledge, which in turn relate to an access to local business networks and alliances in a target market [Johanson, Vahlne, 2009]. Thus, firms can suffer from the liability of outsidership and foreignness and receive the status of 
Search queries used for the bibliometric analysis (2006-2020)

\begin{tabular}{l|c|l}
\hline \multicolumn{1}{c|}{ Search query } & Number of papers & \multicolumn{1}{c}{ Scopus subject area } \\
\hline $\begin{array}{l}\text { "legitimacy" OR "liability of } \\
\text { foreignness" OR "liability of } \\
\text { outsidership" AND "Russia*" }\end{array}$ & 48 & $\begin{array}{l}\text { Business, Management } \\
\text { and Accounting }\end{array}$ \\
\hline "legitimacy" AND "Russia*" & 45 & $\begin{array}{l}\text { Business, Management } \\
\text { and Accounting }\end{array}$ \\
\hline $\begin{array}{l}\text { "liability of foreignness" AND } \\
\text { "Russia*" }\end{array}$ & 3 & $\begin{array}{l}\text { Business, Management } \\
\text { and Accounting }\end{array}$ \\
\hline "liability of outsidership" AND \\
"Russia*"
\end{tabular}

N otes: a final version of the sample was retrieved from the Scopus database in August 2020; we used "Russia*" to also include the word "Russian".

"outsider" in a new foreign market, and "foreignness can just complicate the process of becoming an insider" [Johanson, Vahlne, 2009 , p. 1415]. Gaining the organizational legitimacy by reducing liability of foreignness and outsidership, companies receive the necessary resources and attract more customers and investors/partners [Drori, Honig, 2013].

Scholars emphasize that the organization legitimacy construct is multidimensional and can be studied as an organizational property, process and perception [Suddaby, Bitektine, Haack, 2017]. Legitimacy takes on the role of a property or asset of a company and occurs between an organization and its external environment via the firm's fit to external stakeholders' expectations [Suddaby, Bitektine, Haack, 2017]. Organizational legitimacy also can be studies as a process in which companies try to change their legitimacy and achieve the congruence with the multiple social actors. Firms' perception perspective refers to legitimacy that is based on the consumers' legitimacy judgments and evaluation of the whole companies (e.g. activities and policies), which also incorporates individual and collective cognition [Suddaby, Bitektine, Haack, 2017]. The advantage of the latter perspective is that it is based on and includes all aspects of two other dimensions and provides the most comprehensive view, which corresponds with our research [Prashantham, Kumar, Bhattacharyya, 2019; Suddaby, Bitektine, Haack, 2017].

\subsection{Research on the organizational legitimacy: The Russian context}

The paper is a two-step research that combines bibliometric analysis, using the VOSviewer software, and manual in-depth papers' investigation. The systematic literature search was conducted in the Scopus database. First, to identify main streams of research the clustering analysis was conducted on the basis of existing papers from Russian and international research journals in management and business field for all years. Second, to determine those papers scope and distinctive features, they were manually analyzed and systematized. Overall, we analyzed 48 papers that use "legitimacy" or "liability of foreign- 


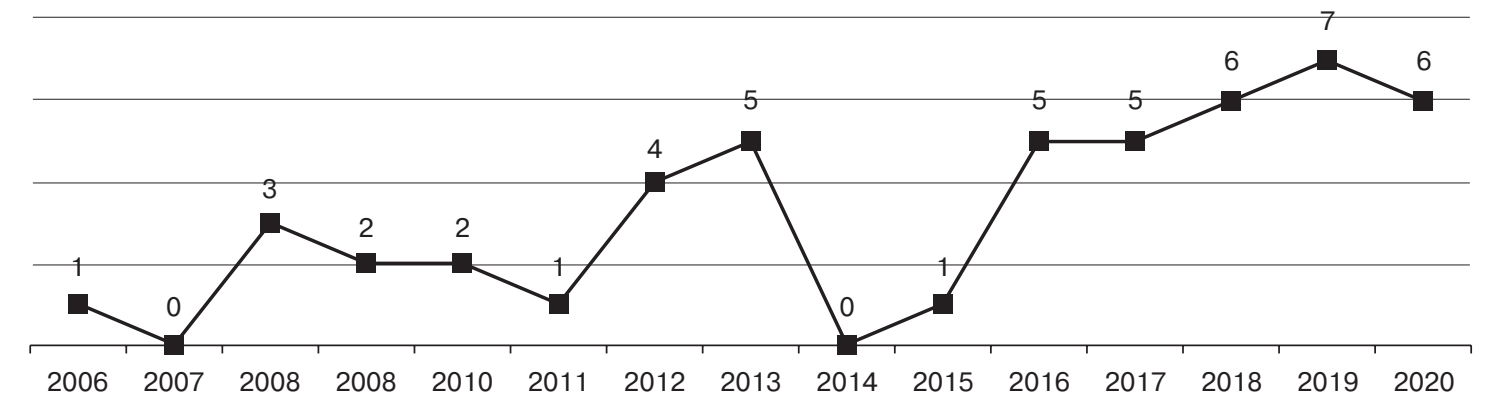

Fig. 1. The number of documents per year: legitimacy with Russian focus in business and management literature (2006-2020)

N ot es: search criteria in database: "legitimacy" OR "liability of foreignness" OR "liability of outsidership" AND “Russia*” AND (LIMIT-TO (DOCTYPE, “ar”)) AND (LIMIT-TO(SUBJAREA, “BUSI”)) AND (LIMIT-TO (SRCTYPE, “j”)); a final version of the sample was retrieved from the Scopus database in August 2020.

ness/outsidership" and Russian context for research (Table 1). Interestingly, there is no any study that has applied the concept of the liability of outsidership.

The graph with the distributed papers (Fig. 1) shows that the spike of the research started to increase since 2016 year and reached the peak of 7 papers in 2019 year. Nowadays the concept of the organizational legitimacy is gaining the increased interest in the Russian research stream. This also reflects the relevance of the topic. Applying the "VOSviewer" software for the bibliometric analysis, four main research clusters were received (Fig. 2). This helps to create a holistic view of existing research on the concept of legitimacy with Russia as a context. Based on the results (Table 2), two main research directions with domestic and international focus were identified (Appendix). Manual analysis of the papers reveals multiple levels of analysis of the implementation of legitimacy construct. Mainly employing the institutional theory as a framework, the papers from Cluster 1 focus on the Russian firms' internationalization path and their liability of foreignness issue abroad [Ermolaeva et al., 2019; Panibratov et al., 2018]. Although the Clusters 2, 3 and 4 have the domestic Russian market focus, they differ in terms of the level of analysis and employed perspectives. The Cluster 2 introduces Russian firms' legitimacy gaining through the CSR strategy [Kuzina, Chernysheva, 2016; Zamir, Saeed, 2020; Zhao, 2012]. The Cluster 3 emphasizes some of the entrepreneurial intensions as managerial delegation decisions (for foreign firms in Russia) [Kulchina, Oxley, 2020] or specific social capital of Russian firms that help to acquire the organization legitimacy in Russia [Iakovleva, Kickul, 2011]. The Cluster 4 has the country level of analysis and investigates the effect of institutional changes occurring in a market and the necessity of the specific state regulation for their easier implementation and legitimacy [Alon, 2013; Alon, Mennicken, Samsonova-Taddei, 2019; Tretyak, Radaev, 2013].

In-depth papers' investigation reveals five levels of analysis applied in the papers about legitimacy: firm level (Russian firms at home and abroad/foreign firms in Russia), individual level [Golyagina, Valuckas, 2020], 


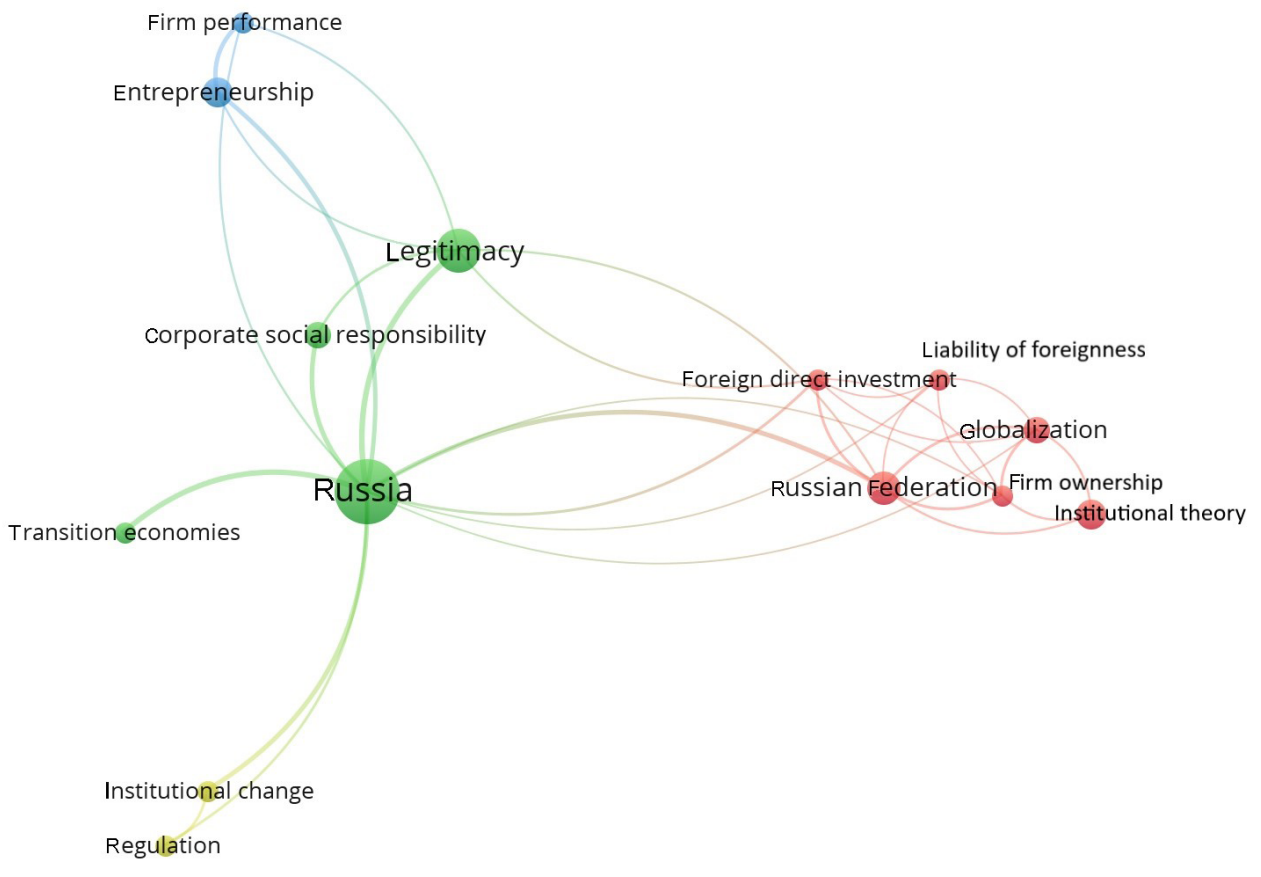

Fig. 2. Clusters received from the bibliometric analysis (VOSviewer screenshot). $\mathrm{N}$ ot e: minimum number of keywords occurrence -2 .

Table 2

Identified clusters and their main focus

\begin{tabular}{|c|c|c|}
\hline Cluster & Keywords & Main focus \\
\hline \multicolumn{3}{|c|}{ International focus } \\
\hline Cluster 1 & $\begin{array}{l}\text { "Foreign direct investment"; "Firm owner- } \\
\text { ship"; "Globalization"; "Institutional } \\
\text { theory"; "Liability of foreignness"; "Russian } \\
\text { Federation" }\end{array}$ & $\begin{array}{l}\text { Firms internationalization and the } \\
\text { liability of foreignness issue }\end{array}$ \\
\hline \multicolumn{3}{|c|}{ Domestic market focus } \\
\hline Cluster 2 & $\begin{array}{l}\text { "Corporate social responsibility"; } \\
\text { "Legitimacy"; "Russia" }\end{array}$ & $\begin{array}{l}\text { Firms legitimacy gaining: the CSR } \\
\text { perspective }\end{array}$ \\
\hline Cluster 3 & "Entrepreneurship"; “Firm performance” & $\begin{array}{l}\text { Entrepreneurial intensions for legiti- } \\
\text { macy gaining }\end{array}$ \\
\hline Cluster 4 & “Institutional change"; “Regulation” & $\begin{array}{l}\text { Necessity of the specific regulation due } \\
\text { to the institutional changes in a market }\end{array}$ \\
\hline
\end{tabular}


industry level [Karhunen, 2008], country level, and government level. In addition to the clusters recognized above, we identified one more research direction that focus on the specific policies of the government, helping to increase its legitimacy in Russia [Aasland, Kropp, Meylakhs, 2020]. For example, the authorities gain legitimacy by contributing into the public welfare, responding to some disasters, or collaborating with non-state actors in policy-making [Aasland, Kropp, Meylakhs, 2020; Fröhlich, Skokova, 2020; Mazepus, van Leeuwen, 2020].

The first main focus of analyzed papers is the domestic market, especially Russian firms and their legitimacy within Russia (Appendix). The first studies have explored firms' legitimacy acquiring in the post-Soviet period. The new market demands required the introduction of new management approaches the legitimacy of those was uncertain [Hultén, Wilson, 2006]. In a similar vein, $\mathrm{P}$. Karhunen emphasized the need for the companies' adaptation to the new hotel industry-level isomorphic pressures during and after transition [Karhunen, 2008]. There is a great role of firms' sensemaking and political connections with Russian state authorities in the process of gaining legitimacy and competitive advantage in Russia [Klarin, Ray, 2019; Klarin, Sharmelly, 2019]. Thus, firms, which maintain links with the government, have political legitimacy, security, and even more opportunities to enter new foreign markets [Klarin, Ray, 2019].

There also is the business-CSR-state relationship focus in the research. The first study on the topic discusses the need for "the ethical turnaround" (i.e. business responsibility for some of the broader civil welfare) that refers to the transformational leadership as a basis for the CSR and proposes this would help to establish firms' credibility and legitimacy in Russia and even abroad [Puffer, McCarthy, 2008]. The CSRbased political legitimacy strategy is important for large Russian companies to meet the pressure from the government, which is the main motivator for firms to apply the
CSR [Kuzina, Chernysheva, 2016; Zhao, 2012]. Firms that apply the CSR satisfy and "take on a role of the government's request on social investments in exchange of the support for the business operation" in the market [Zhao, 2012, p. 442]. To increase organizational legitimacy and to be isomorphic, Russian firms, which located closer to major cities and financial centers, more often implement the CSR [Zamir, Saeed, 2020]. At the same time, the Russian CEOs don't see the CSR activities as the important factor for the positive firms' image formation and legitimacy gaining in Russia [Kuznetsov, Kuznetsova, Warren, 2009; Kuznetsov, Kuznetsova, 2012]. Thus, organizations employ the CSR practices only in order to be isomorphic and gain political legitimacy from the Russian state authorities. There also is the focus on the women-led Russian small and medium-sized enterprises (SMEs) that seek to gain legitimacy in the Russian market [Iakovleva, Kickul, 2011]. The social capital of those firms has the impact on perceptions of legitimacy and financial competence success of these companies [Iakovleva, Kickul, 2011]. Similarly, Russian femaleowned high technology firms, facing with the liabilities of smallness, newness and even gender-associated liabilities, manage their organizational legitimacy by receiving the financial support from foreign parties that help them to gain legitimacy among internal Russian stakeholders [Vershinina et al., 2019].

The single case study presents the indepth investigation of the roots of the Russian oil company Yukos' legitimacy absence, which appear due to the lack of the strategic flexibility and incompatibility of firm' values with its institutional environment [Dixon, Day, 2010] that has the great impact on the business proceeding and legitimacy building in the Russian context [Petrovskaya, Zaverskiy, Kiseleva, 2017]. Three main dimensions of institutions that provide the reason and ground for organizational legitimacy are regulatory (business is legitimate via the conformity of Russian 
firms to the official rules and laws), cognitive (business is legitimate via a common frame of reference: the stereotypes about the entrepreneurship in the Russian society) and normative (business is legitimate via the acceptance of the actual moral norms) [Petrovskaya, Zaverskiy, Kiseleva, 2016; 2017]. Although some of the Russian context' challenges are identified, there are not any specific recommendations introduced how to overcome them by firms.

The second main stream of research has explored how Russian companies acquire the organizational legitimacy for internationalization (Appendix). Being a quite new phenomenon, the study of Russian firms' expanding abroad is important nowadays [Ermolaeva et al., 2019]. Using the petroleum company as a context, the study [Kyj, Kyj, 2010] emphasized that the decrease of the organizational legitimacy of firms has the impact on a firm's operating flexibility. The concept of the liability of foreignness and its main aspect such as the country of origin effect, which occur during the internationalization process of firms, and the mitigation strategies that are necessary to overcome them are investigated and applied to Russian firms, especially the largest Russian energy company Inter RAO UES and Russian IT companies [Panibratov, Ermolaeva, Abramkov, 2015; Panibratov, 2015]. The strategies include the prior analysis of the market (the need for which arises from a lack of experience), partnerships, as well as creation and support of specific local image via marketing, and locally customized products or services [Panibratov, 2015].

Likewise, by focusing on the specific case of Russian companies entering the German market, strategies such as consulting, cooperation with institutional agents and market analysis can also reduce companies' liability of foreignness and increase their organizational legitimacy abroad [Panibratov et al., 2018]. Moreover, there is the great effect of the use of favor (in the Russian context "blat or sviazi") on the Russian firms' internationalization growth path and gain- ing legitimacy process [Puffer et al., 2013]. To gain legitimacy firms can collaborate with the new strategic partners, especially those who have the differentiated profiles [Rezende da Costa et al., 2018]. Applying the institutional theory, the study of [Kiitsak-Prikk, 2017] emphasized the transformation of public cultural organizations abroad under the change of firm status and the necessary basics of three types of legitimacy as regulative (receive the legal status), normative (be moral organization) and cognitive (be culturally supported) in order to be isomorphic. Thus, most studies have emphasized the organizational isomorphism that relate to the macro level of firm and the institutional environment, and just handful of papers have introduced some practices that companies can apply for legitimacy building abroad and the liability of foreignness decrease.

\subsection{Factors of the main pillars of legitimacy}

Although there are many pillars of the organizational legitimacy construct in a literature, four main types are pragmatic, moral or normative, cognitive and regulative [Deephouse et al., 2017]. Three main pillars of the organizational legitimacy construct, which are also assumed to be the most influential ones [Suddaby, Bitektine, Haack, 2017], are cognitive, moral and pragmatic, which can be applied for both domestic and foreign markets [Suchman, 1995]. The cognitive legitimacy refers to a passive evaluation or perception that a firm is both comprehensible and necessary or taken-forgranted, lacking specific judgments, while the pragmatic and moral legitimacy are based on active assessments and judgments formation [Alexiou, Wiggins, 2019]. W. Scott also introduced regulative and normative legitimacy, which are based on the acceptance and following the existing norms and laws [Scott, 2013].

There is a contradiction in a literature about the measurement of the different types 
Measurement scales of different pillars of the organizational legitimacy construct

\begin{tabular}{l|l}
\hline \multicolumn{1}{c|}{ Scale } & \multicolumn{1}{c}{ Author } \\
\hline Normative or moral legitimacy & [Elsbach, 1994] \\
\hline Normative or moral legitimacy & [Elsbach, 1994; Humphreys, Latour, 2013] \\
\hline Moral, pragmatic and cognitive legitimacy & [Díez-Martín, Prado-Roman, Blanco-Gonzalez, 2013] \\
\hline Pragmatic and cognitive legitimacy & [Foreman, Whetten, 2002] \\
\hline Cognitive legitimacy & [Pollack, Rutherford, Nagy, 2012] \\
\hline Moral, pragmatic and cognitive legitimacy & [Alexiou, Wiggins, 2019] \\
\hline Moral, pragmatic and cognitive legitimacy & [Randrianasolo, Arnold, 2020] \\
\hline
\end{tabular}

of the organizational legitimacy construct. The main assumption here is that these pillars provided above mostly are referred to theoretical ones and in empirical studies they aren't separable from each other [Deephouse et al., 2017]. Thus, the possibility of the division of cognitive and moral pillars of legitimacy is a matter of dispute in a literature [Zeitz, Mittal, McAulay, 1999]. Some research underlined that these pillars can be separated from each other but empirically they are identical [Humphreys, Latour, 2013; Zeitz, Mittal, McAulay, 1999]. However, some studies have emphasized that they can be separated both theoretically and empirically [Suchman, 1995]. We adhere to the latter view, and provide analysis of the literature on the pillars apart. There also were identified seven papers with the attempts to directly measure types of the organizational legitimacy construct (Table 3).
A literature search of empirical papers to determine the main factors for each pillar separately was conducted. Basically, we use the Scopus database and manually identify about 35 empirical papers, analyzing and measuring factors that influence and form the pillars of the organizational legitimacy construct. Most of these studies were published in top-tier journals, especially A (4 and $4 *$ ) and B (3) levels, in a list provided by the Association of Business Schools (ABS). The results of the literature analysis are provided in Table 4, which presents the main identified factors for each of the four main pillars.

The most important condition of regulative or sociopolitical legitimacy [Aldrich, Fiol, 1994; Scott, 2013] is the firms' following to the official government regulations. Main factor of the regulative legitimacy is a compliance with legal and regula-

Table 4

Identified clusters and their main focus

\begin{tabular}{|c|c|}
\hline Factor & Articles \\
\hline \multicolumn{2}{|c|}{ Pragmatic legitimacy } \\
\hline Innovativeness & [Alexiou, Wiggins, 2019; Foreman, Whetten, 2002] \\
\hline $\begin{array}{l}\text { Benefits for community/immediate stakeholders/ } \\
\text { employees }\end{array}$ & [Alexiou, Wiggins, 2019; Foreman, Whetten, 2002] \\
\hline Implementation of the TQMs & [Kennedy, Fiss, 2009; Staw, Epstein, 2000] \\
\hline
\end{tabular}


Table 4 (continued)

\begin{tabular}{|c|c|}
\hline Factor & Articles \\
\hline $\begin{array}{l}\text { The quality of products or services/ the quality } \\
\text { of management }\end{array}$ & [Kennedy, Fiss, 2009; Staw, Epstein, 2000] \\
\hline The R\&D (Research \& Development) expenditure & [Deeds, Mang, Frandsen, 2004] \\
\hline Information exchanges with its partners & [Suchman, 1995] \\
\hline $\begin{array}{l}\text { Receiving of outside assistance / asking for } \\
\text { funds }\end{array}$ & [Tornikoski, Newbert, 2007] \\
\hline \multicolumn{2}{|c|}{ Cognitive legitimacy } \\
\hline Size of a firm & [Dobbin et al., 1998; Ruef, Scott, 1998] \\
\hline $\begin{array}{l}\text { Name attributes (based on length, ambiguity, } \\
\text { and domain specificity) }\end{array}$ & [Glynn, Abzug, 2002; Kuilman, Wezal, 2013] \\
\hline $\begin{array}{l}\text { A density is the total number of similar firms in } \\
\text { existence }\end{array}$ & [Kuilman, Wezal, 2013; Hannan, Carrol, 1992] \\
\hline Favorable press coverage & $\begin{array}{l}\text { [Deeds, Mang, Frandsen, 2004; Murphy et al., } \\
\text { 2019; Pollock, Gulati, 2007; Pollack, Rutherford, } \\
\text { Nagy, 2012] }\end{array}$ \\
\hline $\begin{array}{l}\text { Receiving financial or other support from state } \\
\text { or credible centers }\end{array}$ & [Deeds, Mang, Frandsen, 2004] \\
\hline Network activities & $\begin{array}{l}\text { [Human, Provan, 2000; Prashantham, Kumar, } \\
\text { Bhattacharyya, 2019] }\end{array}$ \\
\hline Charitable donations & $\begin{array}{l}\text { [Galaskiewicz, 1985; Golant, Sillince, 2007; } \\
\text { Humphreys, Latour, 2013] }\end{array}$ \\
\hline \multicolumn{2}{|c|}{ Moral legitimacy } \\
\hline $\begin{array}{l}\text { Special practices towards their employees: } \\
\text { tuition reimbursement plans (languages etc.); } \\
\text { bonus plans; flex time; paid sick leave; pain } \\
\text { vacation; retirement plans etc. }\end{array}$ & [Rutherford et al., 2018] \\
\hline $\begin{array}{l}\text { Standards for environmental protection, food } \\
\text { safety, and animal welfare }\end{array}$ & [Elsbach, 1994; Humphreys, Latour, 2013] \\
\hline The CSR practices & [Ahn, Park, 2018] \\
\hline Low rate of employee turnover & [Elsbach, 1994; Humphreys, Latour, 2013] \\
\hline $\begin{array}{l}\text { The total number of owners/the all owners' work } \\
\text { experience/the total number of all owners' indus- } \\
\text { try-specific business started in the past/owners' } \\
\text { educational level }\end{array}$ & $\begin{array}{l}\text { [Cooper et al., 1994; Delmar, Shane, 2004; } \\
\text { Rutherford et al., 2018; Song et al., 2008] }\end{array}$ \\
\hline $\begin{array}{l}\text { Management teams' educational level and } \\
\text { professional experience }\end{array}$ & $\begin{array}{l}\text { [Delmar, Shane, 2004; Rutherford et al., 2018; } \\
\text { Suchman, 1995; Tornikoski, Newbert, 2007] }\end{array}$ \\
\hline $\begin{array}{l}\text { The total number of intellectual property rights, } \\
\text { such as patents, trademarks and copyrights and } \\
\text { the total number of intellectual property rights } \\
\text { licensed out by a firm }\end{array}$ & [Rutherford et al., 2018] \\
\hline
\end{tabular}


Table 4 (end)

\begin{tabular}{l|l}
\hline \multicolumn{1}{c|}{ Factor } & \multicolumn{1}{c}{ Articles } \\
\hline Niche in a market & [Ruef, Scott, 1998] \\
\hline The location choice & [Rutherford et al., 2018] \\
\hline \multicolumn{1}{c}{ Regulative legitimacy } \\
\hline $\begin{array}{l}\text { Compliance with legal and regulatory standards } \\
\begin{array}{l}\text { (a legal business status, payment of taxes, } \\
\text { obtaining employer identification number, and } \\
\text { accreditation data) }\end{array}\end{array}$ & [Delmar, Shane, 2004; Ruef, Scott, 1998; \\
\end{tabular}

tory standards (i.e. a valid legal business status, regular payment of taxes, getting the employer identification number, and accreditation data including certificates) [Delmar, Shane, 2004; Ruef, Scott, 1998; Rutherford et al., 2018]. It is especially important for new ventures as the necessary procedures in the legitimatization process within a target market. Moreover, it contributes to a positive normative evaluation of the organization and its activities [Rutherford et al., 2018]. Since the requirements of regulatory legitimacy are common ones that firms follow in any market and the typology of organizational legitimacy introduced by [Suchman, 1995] is the most influential, we apply it and further focus on moral, pragmatic and cognitive legitimacy that are much more complex pillars.

\section{PROPOSITIONS DEVELOPMENT}

\subsection{Specificity of the Russian context}

The Russian firms suffer from the negative country of origin effect and legitimacy shortage both at home and abroad [Panibratov, 2015; Petrovskaya, Zaverskiy, Kiseleva, 2017]. Reasons for this take place in the specificity of the Russian context and Russian firms' development. Besides, sanctions imposed on Russia complicate Russian firms' legitimacy building abroad [Abramova, Garanina, 2018; Larson, 2019]. In the context of the emerging markets (especially Russia), the government plays a crucial role in the innovative activities, firms' operating procedures and, generally in the business development [McCarthy et al., 2014]. Determinants of the institutional context can help to understand and even predict the activities of firms within a market. Thus, the ties with the government are critical for companies that expect to operate in Russia [McCarthy et al., 2014].

The Russian society has the anti-entrepreneurialism sentiments that have risen in the socialist period that makes the process of increasing legitimacy in Russia even more difficult for firms [Vershinina et al., 2019]. Weak formal institutions and infrastructure, absence of the state support and quite often changing business regulations create such conditions under which businesses cannot properly function [McCarthy et al., 2014; Vershinina et al., 2019]. Moreover, a low competitiveness of Russian firms worldwide also negatively influences legitimacy building abroad and puts companies in a position of "outsiders". This takes roots from the brain drain on the Russian market [Shagalkina et al., 2019], low innovative competitive advantage of Russian firms [McCarthy et al., 2014], and low trust both at home and abroad, which negatively affect consumers and even potential partners [Panibratov, 2015; Petrovskaya, Zaverskiy, Kiseleva, 2017]. Thus, gaining the organizational legitimacy is a quite challenging process in such conditions for Russian firms both operating within a home market and expanding abroad. It is important 
to create a certain understanding of what Russian organizations can do to acquire legitimacy at home and abroad and reduce their liability of foreignness and outsidership.

\subsection{Moral legitimacy}

Moral legitimacy is based on the evaluation about firms' activities and whether it is "the right thing to do" [Suchman, 1995, p. 579]. It should promote and provide the social welfare. Suchman emphasizes that moral legitimacy can refers to one of its' four dimensions. The first dimension is evaluations of the favorable outputs (consequential legitimacy) that refer to the evaluation of the accepted standards of quality [Suchman, 1995]. For example, the paper [Scott, Meyer, 1991] emphasized automobile emission standards, hospital mortality rates and academic test scores as possible firms' outputs' evaluations. The second dimension is the firms' procedural legitimacy. Firms' following the standards for environmental protection, food safety, and animal welfare [Elsbach, 1994; Humphreys, Latour, 2013] and other the CSR practices [Ahn, Park, 2018] are important for appropriate procedures and favorable outputs to enhance companies' moral legitimacy at domestic market and abroad. Because the implementation of the CSR practices by companies in Russia are mainly motivated to build the political legitimacy that is not the full focus of the organizational legitimacy construct, and Russian entrepreneurs do not even see the CSR as a necessary factor for legitimacy gaining in Russia, we propose that it is more significant for firms expanding and building legitimacy abroad to reduce the liability of foreignness [Kuzina, Chernysheva, 2016; Kuznetsov, Kuznetsova, 2012; Zhao, 2012].

The third dimension is the assessment of firms' structures (structural legitimacy) [Suchman, 1995], and the last dimension is the evaluation of the leader and, generally, firm's management team (refers to personal legitimacy) [Suchman, 1995]. The structural, procedural dimensions of the moral legitimacy and the assessment of the leader and the management team of companies are the most important forms of moral legitimacy [Suchman, 1995]. The total amount of the owners' experience and the number of similar businesses started, organizational human capital and the CEOs background assumed to have the significant influence on the moral pillar [Deeds, Mang, Frandsen, 2004; Delmar, Shane, 2004; Rutherford et al., 2018; Tornikoski, Newbert, 2007]. Characteristics of the leader (e.g. CEO) and a staff, including entrepreneur's educational level, management teams' education and professional experience (organizational human capital) have the positive impact on the moral legitimacy [Tornikoski, Newbert, 2007]. Authors of the paper [Deeds, Mang, Frandsen, 2004] provided the possible measure of the organizational human capital as the evaluation of "Top 10 business schools" (it refers to the biographies of the management team in order to determine from which schools, if any, a member of the team had received an MBA). These factors are important as for new as for mature firms. Moreover, it is important whether the company applies special practices toward its qualified employees in order to attract and retain them. For instance, tuition reimbursement plans, bonus plans, flex time, paid sick leave, pain vacation, retirement plans, health plans, stock ownership and others have the significant effect on the positive moral legitimacy formation [Rutherford et al., 2018].

Due to the brain drain within the Russian market, skilled employees' attraction and retention are the most important condition for Russian firms [Shagalkina et al., 2019] that can also increase these companies moral legitimacy. Due to the distinct required conditions, his effect differs among Russian firms that operate at home and abroad. Professional staff with high human capital and networking is more important for Russian firms to gain legitimacy first at home, decreasing liability of outsidership. Whereas, international knowledge and experience are 
important for companies that expand on foreign markets to build their institutional, business and cross-cultural competence and local networking abroad, which suggested being important for decreasing both liability of foreignness [Panibratov, 2015] and outsidership at foreign markets. This is especially significant for Russian SMEs and firms with low legitimacy or international experience. Since emerging market companies have many barriers to operate at advanced economies due to their latecomer status, weak home formal institutions and low competitive disadvantage [Ai, Tan, 2020], international competence is especially important for Russian firms to operate at developed markets. After internationalization, the skilled local natives' employment could be a further strategy to increase firms' legitimacy at the market [Forstenlechner, Mellahi, 2011]. Moreover, due to the imposed sanctions Russian companies have additional challenges and constraints as new normative procedures, standards and prerequisites and others required for entering abroad [Abramova, Garanina, 2018]. Thus, the international knowledge and experience received from attracted skilled staff may not be enough to facilitate entry and build moral legitimacy into markets that imposed sanctions. Thus, we propose the following propositions.

Proposition 1. Russian firms can enhance their moral legitimacy at home by attracting workforce with high human capital and professional background.

Proposition 1a. The effect of Proposition 1 will be mediated by introducing special beneficial practices towards those skilled employees for their attraction and retention.

Proposition $1 b$. The effect of Proposition 1 will be stronger for Russian SMEs and firms with the low legitimacy at home.

Proposition 2. Russian firms can enhance their moral legitimacy by implementing the CSR practices, the effect of which is stronger for Russian companies expanding abroad.

Proposition 3. Russian firms expanding abroad can enhance their moral legitimacy by attracting skilled workforce with international experience/competence.

Proposition 3a. The effect of Proposition 3 will be mediated by introducing the special beneficial practices towards those skilled employees for their attraction and retention.

Proposition $3 b$. The effect of Proposition 3 will be stronger for Russian SMEs or firms lacking experience abroad and developed markets as the host ones.

Proposition $3 c$. Due to many new normative arrangements and challenges introduced, the effect of Proposition 3 will be weaker or even not exist for Russian firms that expect to operate at the host markets, which have imposed sanctions against Russia.

\subsection{Cognitive legitimacy}

M. Suchman emphasized two dimensions that are essential for the cognitive pillar of the organizational legitimacy [Suchman, 1995]. The first is based on comprehensibility or understandability and refer to the existence of the specific patterns in a market, providing credible explanations for the firm and its characteristics. Organizations are legitimate when they are "understandable" [Suchman, 1995, p. 573]. And the second dimension is the taken-for-grantedness [Suchman, 1995]. Some organizations change their names in order to conform or be isomorphic to prevalent practices in their new institutional environment; thus, names attributes can be based on their length, ambiguity, and domain specificity and refer to forms' comprehensibility [Glynn, Abzug, 2002; Kuilman, Wezal, 2013; Suchman, 1995]. Thus, the accepted and legitimate organizational practices, and product or service will encourage the new organizations also have the similar ones in order to be locally customized that are essential for Russian firms' successful expanding abroad [Panibratov, 2015]. Marketing, promotional efforts [Tornikoski, Newbert, 2007] and favorable press coverage of a company or even industry have the influence on the cog- 
nitive legitimacy too [Deeds, Mang, Frandsen, 2004; Murphy et al., 2019; Pollock, Gulati, 2007]. This will decrease Russian firms' liability of foreignness at foreign markets.

Companies that have received financial or other support from the government or other credible centers have the greater legitimacy [Deeds, Mang, Frandsen, 2004]. Thus, firms' involvement with others in the network is essential factor for the cognitive legitimacy formation via "cognitive consistency" in both domestic market and abroad [Human, Provan, 2000; Low, Johnston, 2008]. It results in the positive cognitive commitment and resources attainment [Human, Provan, 2000]. Thus, the partnership with high-status legitimate firms provides the positive cognitive legitimacy formation via legitimacy spillover [Drori, Honig, 2013; Prashantham, Kumar, Bhattacharyya, 2019; Tost, 2011]. Due to the Russian firms' negative country of origin effect and legitimacy shortage [Panibratov, 2015; Petrovskaya, Zaverskiy, Kiseleva, 2017], cooperation with legitimate partners is a significant factor for Russian firms' cognitive legitimacy gaining both at home and abroad, decreasing firms liability of outsidership. However, due to the Western-US sanctions against Russia, a shift in the composition of the partnerships and alliances for Russian firms takes place such that there is a decreasing of collaborations with partners from West countries and increasing firms' ties with Asian ones [Abramova, Garanina, 2018]. Thus, we propose:

Proposition 4. Russian firms can enhance their cognitive legitimacy at home by networking with high-status legitimate foreign and/or domestic enterprises.

Proposition 5. Russian firms can enhance their cognitive legitimacy at home by introducing favorable marketing promotional efforts and press coverage.

Proposition 5a. The effects of Proposition 4 and Proposition 5 will be stronger for Russian SMEs and firms with the low legitimacy at home.

Proposition 6. Russian firms expanding abroad can build their positive cognitive legitimacy by networking with high-status legitimate foreign enterprises.

Proposition 7. Russian firms expanding abroad can build their positive cognitive legitimacy abroad by introducing favorable marketing promotional efforts and press coverage, and locally customized products or services.

Proposition 7a. The effect of Proposition 6 and Proposition 7 will be stronger for Russian SMEs or firms lacking experience abroad and developed markets as the host ones.

Proposition $7 b$. The effect of Proposition 6 will be negatively moderated for Russian firms that expect to operate at the host markets, which have imposed sanctions against Russia because of the challenges associated with partnerships with companies from those economies.

\subsection{Pragmatic legitimacy}

Pragmatic legitimacy or self-interested calculations promotes that organizational activities have the effect on the firms audience's well-being. Suchman emphasized three dimensions of the pragmatic legitimacy such as the exchange, influence and dispositional legitimacy [Suchman, 1995, p. 578]. Influence dimension refers to firm responsiveness to the external stakeholders' larger interests [Suchman, 1995]. The exchange dimension of firm refers to the involvement to some beneficial for both parties relations [Tornikoski, Newbert, 2007]. The dispositional dimension of the pragmatic legitimacy refers to attributions such as "organizations have our best interests at heart that share our values, or are honest" so on [Suchman, 1995, p. 578]. We identified such factors as firms' innovativeness, R\&D intensity, quality of the management and products or services as significant factors of the pragmatic pillar of legitimacy [Deeds, Mang, Frandsen, 2004; Foreman, Whetten, 2002; Hargadon, Douglas, 2001; Rao, 1994].

The adaptation of popular total quality management techniques (TQMs) for improv- 
ing the quality of products and services is positively associated with the pragmatic legitimacy [Westphal, Gulati, Shortell, 1997]. Due to the globalization and such issues as environmental and operational safety, sustainable customers' products demand, new formal requirements and standards, there is a need for Russian companies to implement global experience as the TQMs to improve their pragmatic legitimacy [Balashova, Gromova, 2017]. According to [Suchman, 1995], it is important in the process of maintaining legitimacy and gaining firms' innovativeness to find the balance between very rapid technological innovations or even unaddressed innovations for a significant period of time. Firm's innovativeness is important to stay competitive at domestic home market and in pursuit of international markets, which concern the modification or improvement of products/service (to satisfy market needs) and processes technologies, and include the development of innovations for future needs or responding to present accidental technology activities and unexpected decisions introduced by rivals in a market. It helps emerging market firms both to answer employees' internal and consumers/partners' external expectations about the necessary level of the company's technological development in some new markets (especially developed) or conquer other markets (especially developing) with firms' innovative solutions and products, increasing legitimacy of those organizations. This also reduced both Russian firms liability of foreignness and outsidership abroad. With the increasing digitalization of the Russian market, the need for Russian companies to introduce digital technologies is also growing [Nosova et al., 2019].

Considering that not all Russian organizations are founded with the necessary level of the technological development (e.g. technological innovation activities are mostly applied by Russian large international companies $(75 \%)$ than by the SMEs $(30 \%))$ and Russian firms usually lag behind foreign organizations from more advanced innovative economies [McCarthy et al., 2014; Skolkovo,
TusPark, 2016], they have the pragmatic legitimacy shortage. Therefore, we propose:

Proposition 8. Russian firms can enhance their pragmatic legitimacy at home by introducing technological innovations and the TQMs.

Proposition 8a. The effect of Proposition 8 will be stronger for Russian SMEs and firms that lag behind in innovative activities.

Proposition 9. Russian firms expanding abroad can enhance their pragmatic legitimacy by introducing technological innovations and the TQMs.

Proposition 9a. The effect of Proposition 9 will be stronger for Russian SMEs or firms that lag behind in innovative activities and developed markets as the host ones.

\subsection{Mutual pillars reinforcement}

Although all three types are distinct and have both the internal and external view at the organization, the cognitive legitimacy relates to the external legitimacy formation process and primarily appears among external stakeholders (consumers/society/partners) while the pragmatic and moral legitimacy are more relevant first to the internal legitimacy formation [Drori, Honig, 2013; Tost, 2011]. There also is the mutual reinforcement effect between both the pragmatic and moral internal legitimacy formation and the cognitive external legitimacy gaining process [Alexiou, Wiggins, 2019; Prashantham, Kumar, Bhattacharyya, 2019]. Judgments and perception of a company being pragmatically and morally legitimate lead to these organization becoming also cognitively legitimate and vice versa [Alexiou, Wiggins, 2019]. For example, digitalization of Russian companies, which initially serves for internal processes, product or service improvements (i.e. pragmatic legitimacy), also helps to attract and even retain potential customers, increasing the cognitive legitimacy of those firms [Nosova et al., 2019]. In a similar vein, there is a mutual reinforcement mechanism of some factors between moral and cognitive 
legitimacy: the charitable donations are assumed to be important for cognitive pillar of the organizational legitimacy, but they also can influence the moral one [Galaskiewicz, 1985; Golant, Sillince, 2007; Humphreys, Latour, 2013] or the top management team is a key factor of the moral legitimacy, having the effect on the cognitive legitimacy too [Pollack, Rutherford, Nagy, 2012].

\section{CONCLUSION AND DISCUSSION}

The organizational legitimacy is the most important driving force for firms' success [Caussat, Prime, Wilken, 2019; Kostova, Zaheer, 1999; Prashantham, Kumar, Bhattacharyya, 2019]. This study contributes to the international business (IB) and Russian streams of research about the Russian firms legitimatization processes by systematizing and analyzing existing papers and collecting the factors of main legitimacy' pillars. Specifically, we contribute to the legitimacy literature, responding to many calls to study the microfoundations of firms organizational legitimacy gaining. Because studies in the emerging market context are scarce, we also add to the literature, developing the theoretical framework based on the specificity of the the Russian context.

Managerially, our findings are of practical importance for Russian managers and entrepreneurs, proposing the factors to focus on for the effective strategic management, while establishing the organizational legitimacy. We have identified groups of separate factors for both the domestic Russian market and foreign ones. First, the workforce with the high human capital and professional background is important for firms' moral legitimacy building at home. When expanding overseas, firms must employ the CSR and hire personnel with international experience/knowledge, which are important for decreasing both liability of foreignness and outsidership at foreign markets. Second, introducing favorable marketing pro- motional efforts and press coverage are significant for cognitive legitimacy building at both home and foreign markets; whereas, the locally legitimate organizational practices and customized products or services are important for Russian firms expanding abroad. This will reduce companies' liability of foreignness. Similarly, networking with high-status legitimate foreign or domestic enterprises could help to gain or build cognitive legitimacy at both Russian and foreign markets via legitimacy spillover and decreased firms' liability of outsidership. Third, technological innovations and the TQMs are important for pragmatic legitimacy to be insider of the specific innovation networks. The mediating and moderating effects as the firms' size or the context specific factors as sanctions and others were also introduced and analyzed. In addition, we hope that the aggregated factors of legitimacy will stimulate future studies about the micro level of the processes of the organizational legitimacy building by companies in other emerging markets. This will help identify significant factors for each of the markets studied. Future research may enhance our insights by adding an industry specification and further empirically test the suggested propositions. Despite these theoretical and managerial contributions, this study has some limitations. Because the provided literature analysis was predominantly based on the Scopus database, and we mainly used the toptier journals to determine legitimacy factors, the paper might have missed some potentially relevant papers and factors from the analysis.

\section{ACKNOWLEDGEMENTS}

Authors thank International Business Department at the Darla Moore School of Business (University of South Carolina) and personally Tatiana Kostova for the helpful feedback during and after the research seminar, where the current research was presented. 


\section{Papers with the legitimacy and Russian market focus}

\begin{tabular}{c|c}
\hline Article & Focus \\
\hline
\end{tabular}

International focus: Firm level

[Kyj, Kyj, 2010]

[Puffer et al., 2013]

[Panibratov, 2015]

[Kiitsak-Prikk, 2017]

[Panibratov et al., 2018]

[Rezende da Costa et al., 2018]

[Ermolaeva et al., 2019]
The research proposes that the decreasing of legitimacy impacts a firm's operating flexibility

The effect of the use of favor (in the Russian context "blat or sviazi") on the Russian firms' internationalization growth path and gaining legitimacy process

The research investigates the sources of liability of foreignness and the country-of-origin effect on Russian IT-firms

The study emphasizes the transformation of public cultural organizations abroad and basis of three types of legitimacy as regulative (legal status), normative (be moral) and cognitive (be culturally supported) to be isomorphic and firms possibility to maintain them after change of legal status

Introduce the effects of liability of foreignness of Russian firms penetrating the German market and suggest strategies to mitigate them

Emphasize the configuration of the alliance portfolio to seek legitimacy, prioritizing partners with differentiated profiles

Introduce factors that determine Global value chain strategies. Suffering from the country of origin effect due to host and home instructional distances, Russian IT-firms seek to gain legitimacy abroad in order to be isomorphic

Domestic Russian market focus: firm level

[Hultén, Wilson, 2006]

[Puffer, McCarthy, 2008]

[Kuznetsov, Kuznetsova, Warren, 2009; Kuznetsov, Kuznetsova, 2012]

[Dixon, Day, 2010]

[Iakovleva, Kickul, 2011]

[Zhao, 2012]
Discuss the legitimacy of new management approaches in post-Soviet companies, the need for which rise from the new market demands

Discuss the need for "the ethical turnaround" that refers to the transformational leadership as a basis for the CSR (i.e. business responsibility for some of the broader civil welfare). This help to establish firms' credibility and legitimacy in Russia and even abroad

The paper investigates the attitudes of Russian executives towards corporate social responsibility. The Russian CEOs don't see CSR activities as the important factor for the positive firms' image and legitimacy in Russia

Emphasize a lack of legitimacy of Russian oil company Yukos that rise due to the absence of the strategic flexibility and incompatibility of organizational values with the institutional environment

The paper focuses on the women-led Russian SMEs that seek to gain legitimacy in the Russian market. Thus, perceived legitimacy plays a key role in signaling to others the credibility of the firm

The paper focuses on the political legitimacy by specifying a typology of CSR-based legitimacy strategies of Russian firms 
Appendix (end)

\begin{tabular}{l|l}
\hline \multicolumn{1}{c|}{ Article } & \multicolumn{1}{c}{ Focus } \\
\hline [Tretyak, Radaev, 2013] & $\begin{array}{l}\text { Introduce the need of socio-political legitimacy for the new rules of } \\
\text { firms' exchange in the retail chains that undergo the relational } \\
\text { conflicts and institutional change }\end{array}$ \\
\hline [Kuzina, Chernysheva, 2016] & $\begin{array}{l}\text { The CSR-based political legitimacy strategy is important for large } \\
\text { Russian companies to meet the pressure from the government }\end{array}$ \\
\hline [Klarin, Ray, 2019; Klarin, \\
Sharmelly, 2019] & $\begin{array}{l}\text { Introduce the great role of the political connections in the process of } \\
\text { sensemaking and gaining legitimacy by Russian firms }\end{array}$ \\
\hline [Zamir, Saeed, 2020] & $\begin{array}{l}\text { To increase organizational legitimacy and be isomorphic, Russian } \\
\text { firms located closer to major cities and financial centers show more } \\
\text { CSR disclosure }\end{array}$ \\
\hline
\end{tabular}

Domestic Russian market focus: individual level

\begin{tabular}{l|l}
\hline [Golyagina, Valuckas, 2020] & $\begin{array}{l}\text { Applying the management accounting, the paper shows that the } \\
\text { boundary-work (differentiation of one professional group from } \\
\text { another) help to gain legitimacy by members having the IMA certifica- } \\
\text { tion at }\end{array}$ \\
\hline
\end{tabular}

Domestic Russian market focus: industry level

\begin{tabular}{l|l}
\hline [Karhunen, 2008] & $\begin{array}{l}\text { Analyze enterprise adaptation to the hotel industry-level isomorphic } \\
\text { pressures during and after transition in post-Soviet period }\end{array}$ \\
\hline \multicolumn{2}{c}{ Domestic Russian market focus: foreign firms' legitimacy } \\
\hline [Kulchina, Oxley, 2020] & $\begin{array}{l}\text { Emphasize the distinctive features of foreign entrepreneurs' manage- } \\
\text { rial delegation decisions. Contracting impediments constitute one } \\
\text { important aspect of the "liability of foreignness" for foreign firms in } \\
\text { Russia }\end{array}$ \\
\hline
\end{tabular}

N ot e: all data were retrieved from the Scopus database.

\section{REFERENCES}

Aasland A., Kropp S., Meylakhs A. Y. 2020. Between collaboration and subordination: State and non-state actors in Russian antidrug policy. Voluntas 31 (2): 422-436.

Abramova A., Garanina O. 2018. Russian MNEs under sanctions: Challenges for upgrading in GVCs (Cases of energy and IT industries). Journal of East-West Business $\mathbf{2 4}$ (4): 371-391.

Ahn S.-Y., Park D.-J. 2018. Corporate social responsibility and corporate longevity: The mediating role of social capital and moral legitimacy in Korea. Journal of Business Ethics 150 (1): 117-134.

Ai Q., Tan H. 2020. Uncovering neglected success factors in post-acquisition reverse capability transfer: Evidence from Chinese multinational corporations in Europe. Journal of World Business 55 (3): 101053 (in press).

Aldrich H. E., Fiol C. M. 1994. Fools rush in? The institutional context of industry creation. Academy of Management Review 19: 645-670. 
Alexiou K., Wiggins J. 2019. Measuring individual legitimacy perceptions: Scale development and validation. Strategic Organization 17 (4): 470-496.

Alon A. 2013. Complexity and dual institutionality: The case of IFRS adoption in Russia. Corporate Governance: An International Review 21 (1): 42-57.

Alon A., Mennicken A., Samsonova-Taddei A. 2019. Dynamics and limits of regulatory privatization: Reorganizing audit oversight in Russia. Organization Studies 40 (8): 1217-1239.

Balashova E. S., Gromova E. A. 2017. TQM as one of the drivers of Russian industrial sector. Quality-Access to Success $\mathbf{1 8}$ (159): 50-53.

Caussat P., Prime N., Wilken R. 2019. How multinational banks in India gain legitimacy: Organizational practices and resources required for implementation. Management International Review 59: 561591.

Cooper A. C., Gimeno-Gascon F. J., Woo C. Y. 1994. Initial human and financial capital as predictors of new venture performance. Jour nal of Business Venturing 9 (5): 371-395.

Deeds D. L., Mang P. Y., Frandsen M. L. 2004. The influence of firms' and industries' legitimacy on the flow of capital into high-technology ventures. Strategic Organization 2 (1): 9-34.

Deephouse D. L. 1996. Does isomorphism legitimate? Academy of Management Jour nal 39 (4): 1024-1039.

Deephouse D. L., Bundy J., Tost L. P., Suchman M. C. 2017. Organizational legitimacy: Six key questions. In: R. Greenwood, C. Oliver, T. Lawrence, R. Meyer (eds). The Handbook of Organizational Institutionalism, 27-52. Sage: London.

Delmar F., Shane S. 2004. Legitimating first: Organizing activities and the survival of new ventures. Journal of Business Venturing 19 (3): 385-410.

Díez-Martín F., Prado-Roman C., Blanco-Gonzalez A. 2013. Beyond legitimacy: Legitimacy types and organizational success. Management Decision 51 (10): 1954-1969.
Dixon S., Day M. 2010. The rise and fall of Yukos: A case study of success and failure in an unstable institutional environment. Journal of Change Management 10 (3): 275-292.

Dobbin F., Edelman L., Meyer J., Scott W. R., Swidler A. 1988. the expansion of due process in organizations. In: Lynne G. Zucker (eds). Institutional Patterns and Organizations: Culture and Environment, 71-100. Ballinger: Cambridge.

Drori I., Honig B. 2013. A process model of internal and external legitimacy. Organization Studies 34 (3): 345-376.

Elsbach K. D. 1994. Managing organizational legitimacy in the California cattle industry: The construction and effectiveness of verbal accounts. Administrative Science Quarterly 39 (1): 57-88.

Ermolaeva L., Nefedov K., Panibratov A., Viktorov D. 2019. Internationalisation Driving value chain configuration: The case of emerging market IT companies. Journal of East-West Business 25 (4): 340-362.

Foreman P., Whetten D. A. 2002. Members' identification with multiple-identity organizations. Organization Science 13 (6): 618-635.

Forstenlechner I., Mellahi K. 2011. Gaining legitimacy through hiring local workforce at a premium: The case of MNEs in the United Arab Emirates. Journal of World Business 46 (4): 455-461.

Fröhlich C., Skokova Y. 2020. Two for one: Public welfare and regime legitimacy through state funding for CSOs in Russia. Voluntas 31 (4): 698-709.

Galaskiewicz J. 1985. Interorganizational relations. Annual Review of Sociology 11: 281-304.

Golant B. D., Sillince J. A. A. 2007. The constitution of organizational legitimacy: A narrative perspective. Organization Studies 28 (8): 1149-1167.

Golyagina A., Valuckas D. 2020. Boundarywork in management accounting: The case of hybrid professionalism. British Accounting Review 52 (2): 100841 
Glynn M. A., Abzug R. 2002. Institutionalizing identity: Symbolic isomorphism and organizational names. The Academy of Management Journal 45 (1): 267-280.

Hannan M. T., Carroll G. R. 1992. Dynamics of Organizational Populations. Oxford University Press: Oxford.

Hargadon A. B., Douglas J. Y. 2001. When innovations meet institutions: Edison and the design of the electric light. Administrative Science Quarterly 46 (3): 476-501.

Hultén P., Wilson T. L. 2006. Contextual influence on diffusion of market-oriented approaches in post-Soviet companies. Journal of East-West Business 12 (1): 5-28.

Human S. E., Provan K. G. 2000. Legitimacy building in the evolution of smallfirm multilateral networks: A comparative study of success and demise. Administrative Science Quarterly 45 (2): 327-365.

Humphreys A., Latour K. A. 2013. Framing the game: Assessing the impact of cultural representations on consumer perceptions of legitimacy. Journal of Consumer Research 40 (4): 773-795.

Iakovleva T., Kickul J. 2011. Beyond social capital: The role of perceived legitimacy and entrepreneurial intensity in achieving funding success and superior venture performance in women-led Russian SMEs. International Journal of Entrepreneurship and Small Business 14 (1): 13-38.

Johanson J., Vahlne J.-E. 2009. The Uppsala internationalization process model revisited: From liability of foreignness to liability of outsidership. Journal of International Business Studies 40 (9): 14111431.

Karhunen P. 2008. Toward convergence in the St. Petersburg hotel industry through the lens of institutional theory. Journal of East European Management Studies 13 (2): 106-128.

Kennedy M. T., Fiss P. C. 2009. Institutionalization, framing, and diffusion: The logic of TQM adoption and implementation decisions among U.S. hospitals. Academy of Management Journal 52 (5): $897-$ 918.
Kiitsak-Prikk K. 2017. Legitimacy and social impact in the context of changing public cultural organizations. Journal of Arts Management Law and Society $\mathbf{4 7}$ (2): 105-117.

Klarin A., Ray P. K. 2019. Political connections and strategic choices of emerging market firms: Case study of Russia's pharmaceutical industry. International Journal of Emerging Markets 14 (3): 410-435.

Klarin A., Sharmelly R. 2019. Strategic sensemaking and political connections in unstable institutional contexts. Journal of Management Inquiry (in press). https:// doi.org/10.1177/1056492619862635

Kostova T., Zaheer S. 1999. Organizational legitimacy under conditions of complexity: The case of the multinational enterprise. Academy of Management Review $\mathbf{2 4}$ (1): $64-81$.

Kostova T., Roth K. Dacin M. T. 2008. Institutional theory in the study of multinational corporations: A critique and new directions. Academy of Management Review 33 (4): 994-1006.

Kuilman J. G., Wezel F. C. 2013. Taking off: Category contrast and organizational mortality in the UK airline industry, 191964. Strategic Organization 11 (1): 56-77.

Kulchina E., Oxley J. 2020. Relational contracts and managerial delegation: Evidence from foreign entrepreneurs in Russia. $\mathrm{Or}$ ganization Science 31 (3): 628-648.

Kuzina O., Chernysheva M. 2016. Corporate charity and corporate philanthropy in Russia: An economic sociology analysis. Voprosy Ekonomiki 3: 115-130. (In Russian)

Kuznetsov A., Kuznetsova O., Warren R. 2009. CSR and the legitimacy of business in transition economies: The case of Russia. Scandinavian Journal of Management 25 (1): $37-45$.

Kuznetsov A., Kuznetsova O. 2012. Business legitimacy and the margins of corporate social responsibility in the Russian context. International Studies of Management \& Organization 42 (3): 35-48.

Kyj M. J., Kyj L. S. 2010. A relational framework for analyzing ventures in cognitive

PЖM 18 (3): 289-312 (2020) 
environments: Illustrations from the TNKBP experience. Journal of East-West Business 16 (4): 340-360.

Larson D. W. 2019. An equal partnership of unequals: China's and Russia's new status relationship. International Politics. https:// doi.org/10.1057/s41311-019-00177-9

Li J., Fleury M. T. L. 2020. Overcoming the liability of outsidership for emerging market MNEs: A capability-building perspective. Journal of International Business Studies 51 (1): 23-37.

Low B., Johnston W. 2008. Securing and managing an organization's network legitimacy: The case of Motorola China. Industrial Marketing Management 37 (7): 873-879.

Mazepus H., van Leeuwen F. 2020. Fairness matters when responding to disasters: An experimental study of government legitimacy. Governance 33 (3): 621-637.

McCarthy D. J., Puffer S. M., Graham L. R., Satinsky D. M. 2014. Emerging innovation in emerging economies: Can institutional reforms help Russia break through its historical barriers? Thunderbird International Business Review 56 (3): 243260.

Murphy P. J., Pollack J., Nagy B., Rutherford M., Coombes S. 2019. Risk tolerance, legitimacy, and perspective: Navigating biases in social enterprise evaluations. Entrepreneurship Research Journal 9 (4).

Nosova S. S., Kolodnyaya G. V., Bondarev S. A., Verigo S. A., Kudryashov A. B. 2019. Digital business as a driver of economic growth in Russia. Espacios 40 (24).

Panibratov A. Yu. 2015. Liability of foreignness of emerging market firms: The country of origin effect on Russian IT companies. Journal of East-West Business 21 (1): 22-40.

Panibratov A. Yu., Ermolaeva L. A., Abramkov A. E. 2015. The liability of foreignness in the internationalization process of Russian energy companies. Vestnik Sankt-Peterburgskogo Universiteta. Menedzment 2: 39-73. (In Russian)

Panibratov A., Ribberink N., Veselova A., Nefedov K. 2018. Entry modes and liabil- ity of foreignness effects: Evidence from Russian firms on the German market. Organizations and Markets in Emerging Economies 9 (1): 106-122.

Petrovskaya I., Zaverskiy S., Kiseleva E. 2016. Putting assumptions into words: money and work beliefs and legitimacy of entrepreneurship in Russia. European $\mathrm{J}$. International Management 10 (2): 157180.

Petrovskaya I., Zaverskiy S., Kiseleva E. 2017. Attitude to entrepreneurship in Russia: Three-dimensional institutional approach. Advances in Systems Science and Applications 17 (2): 29-42.

Pollock T. G., Gulati R. 2007. Standing out from the crowd: the visibility-enhancing effects of IPO-related signals on alliance formation by entrepreneurial firms. Strategic Organization 5 (4): 339-372.

Pollack J. M., Rutherford M. W., Nagy B. G. 2012. Preparedness and cognitive legitimacy as antecedents of new venture funding in televised business pitches. Entrepreneurship Theory and Practice 36 (5): 915939.

Prashantham S., Kumar K., Bhattacharyya S. 2019. International new ventures from emerging economies: Network connectivity and legitimacy building. Management and Organization Review 15 (3): 615-641.

Puffer S. M., McCarthy D. J. 2008. Ethical turnarounds and transformational leadership: A global imperative for corporate social responsibility. Thunderbird International Business Review 50 (5): 303314.

Puffer S. M., McCarthy D. J., Jaeger A. M. Dunlap D. 2013. The use of favors by emerging market managers: Facilitator or inhibitor of international expansion? Asia Pacific Journal of Management 30: 327349.

Randrianasolo A. A., Arnold M. J. 2020. Consumer legitimacy: Conceptualization and measurement scales. Journal of Consumer Marketing 37 (4): 385-397.

Rao H. 1994. The social construction of reputation: Certification contests, legitima- 
tion, and the survival of organizations in the American automobile industry: 18951912. Strategic Management Journal 15 (1): 29-44.

Rezende da Costa P., Silva Braga Junior S., Silveira Porto G., Martinez M. P. 2018. Relational capability and strategic alliance portfolio configuration: A study of Brazilian technology firms. International Journal of Emerging Markets 13 (5): 10261049.

Ruef M., Scott W. R. 1998. A multidimensional model of organizational legitimacy: Hospital survival in changing institutional environments. Administrative Science Quarterly 43 (4): 877-904.

Rutherford M. W., Mazzei M. J., Oswald S. L., Jones-Farmer L. A. 2018. Does establishing sociopolitical legitimacy overcome liabilities of newness? A longitudinal analysis of top performers. Group \& Organization Management 43 (6): 906-935.

Scott W. R., Meyer J. W. 1991. The organization of societal sectors. In: W. W. Powell, P. J. DiMaggio (eds). The New Institutionalism in Organizational Analysis, 108140. University of Chicago Press: Chicago.

Scott W. R. 2013. Institutions and Organizations: Ideas, Interests, and Identities. Sage: Thousand Oaks, CA.

Shagalkina M. V., Latukha M. O., Mitskevich E. A., Strogetskaya E. V. 2019. Factors of migration intentions of talented graduates from leading Russian universities. Russian Management Journal 17 (4): 445-466. (In Russian)

Skolkovo, TusPark. 2016. Russia and China: Innovation and Entrepreneurship. [Electronic resource]. https://www.fbacs.com/upload/ Report_RUS.pdf (accessed: 01.08.2020). (In Russian)

Song M., Podoynitsyna K., van der Bij H., Halman J. I. M. 2008. Success factors in new ventures: A meta-analysis. Journal of Product Innovation Management 25: 7-27.

Suddaby R., Bitektine A., Haack P. 2017. Legitimacy. Academy of Management Annals 11 (1): 451-478.
Staw B. M., Epstein L. D. 2000. What bandwagons bring: Effects of popular management techniques on corporate performance, reputation, and CEO pay. Administrative Science Quarterly 45 (1): 523-556.

Suchman M. C. 1995. Managing legitimacy: Strategic and institutional approaches. Academy of Management Review 20 (3): 571-610.

Tost L. T. 2011. An integrative model of legitimacy judgments. Academy of Management Review 36 (4): 686-710.

Tornikoski E. T., Newbert S. L. 2007. Exploring the determinants of organizational emergence: A legitimacy perspective. Journal of Business Venturing 22 (2): 311-335.

Tretyak O., Radaev V. 2013. Market power and relational conflicts in Russian retailing. Journal of Business \& Industrial Marketing 28 (3): 167-177.

UNCTAD. 2019. World Investment Report 2019: Key Messages and Overview. [Electronic resource]. https://unctad.org/en/ PublicationsLibrary/wir2019_overview_ en.pdf (accessed: 10.09.2019).

UNCTAD. 2020. World Investment Report 2020: International Production beyond the Pandemic. United Nations [Electronic resource]. https://unctad.org/en/PublicationsLibrary/wir2020_en.pdf (accessed: 28.08.2020).

Vershinina N., Rodgers P., Tarba S., Khan Z., Stokes P. 2019. Gaining legitimacy through proactive stakeholder management: The experiences of high-tech women entrepreneurs in Russia. Journal of Business Research (in press).

Westphal J. D., Gulati R., Shortell S. M. 1997. Customization or conformity? An institutional and network perspective on the content and consequences of TQM adoption. Administrative Science Quarterly 42 (2): 366-394.

Zaheer S. 1995. Overcoming the liability of foreignness. Academy of Management Journal 38 (2): 341-363.

Zaheer S., Lamin A., Subramani M. 2009. Cluster capabilities or ethnic ties? Loca-

PЖM 18 (3): 289-312 (2020) 
tion choice by foreign and domestic entrants in the services offshoring industry in India. Journal of International Business Studies 40 (6): 944-968.

Zamir F., Saeed A. 2020. Location matters: Impact of geographical proximity to financial centers on corporate social responsibility (CSR) disclosure in emerging economies. Asia Pacific Journal of Management 37 (1): 263-295.

Zeitz G., Mittal V., McAulay B. 1999. Distinguishing adoption and entrenchment of management practices: A framework for analysis. Organization Studies 20 (5): 741776.

Zhao M. 2012. CSR-based political legitimacy strategy: Managing the state by doing good in China and Russia. Journal of Business Ethics 111 (4): 439-460.

Zimmerman M. A., Zeitz G. J. 2002. Beyond survival: Achieving new venture growth by building legitimacy. Academy of Management Review 27 (3): 414431.

Initial submission: June 11, 2020

Final version accepted:

October 5, 2020

Организационная легитилность российских фирл: контекстуальная специфика и стратегии легитилизации

\section{А. Ю. Панибратов, Л. Е. Рысакова}

Институт «Высшая школа менеджмента», Санкт-Петербургский государственный университет, Россия

Российские фирмы страдают от негативного влияния эффекта «страны происхождения» и нехватки легитимности. Цель статьи - выявление факторов, на которые должны обратить внимание российские компании в процессе своей легитимизации как на внутреннем рынке, так и за рубежом. Для определения направлений исследований были проанализированы 48 статей из журналов по менеджменту и бизнесу посредством применения библиометрического анализа и метода ручного углубленного изучения их тематики. Исходя из специфики российского контекста и анализа литературы о факторах легитимности, в данной работе представлена теоретическая основа и выдвинуты предположения о возможных стратегиях легитимизации российских фирм. Три основных типа организационной легитимности - моральная, прагматическая и когнитивная, - которые считаются наиболее влиятельными в литературе, проанализированы и систематизированы; кроме того, приведены стратегии повышения российскими фирмами своей легитимности в России и за ее пределами. Работа вносит вклад в исследования легитимности, отвечая на многие предложения по изучению микрооснов формирования организационной легитимности в разных контекстах. Полученные результаты имеют практическое значение для менеджеров и предпринимателей, внимание которых направлено на эффективное стратегическое управление и укрепление легитимности российских компаний как внутри страны, так и за рубежом.

Ключевые слова: бремя иностранца, бремя аутсайдера, организационная легитимность, моральная легитимность, прагматическая легитимность, когнитивная легитимность, Россия. 
JEL: L20.

For citation: Panibratov A. Yu., Rysakova 2020 L. E. The organizational legitimacy of Russian firms: Contextual specificity and legitimization strategies. Russian Management Journal 18 (3): 289-312.

Статья поступила в редакиию 11 июня 2020 г. Принята к публикаиии 5 октября 2020 г. 